\title{
Staying on Course: The Effects of Savings and Assets on the College Progress of Young Adults
}

\author{
WILLIAM ELLIOTT \\ University of Pittsburgh \\ SONDRA BEVERLY \\ Washington University in St. Louis
}

Increasingly, college graduation is seen as a necessary step toward achieving the American Dream. However, large disparities exist in graduation rates. For many families, the current family income is not enough to finance college. Therefore, many young adults have to rely on education loans, which may be difficult to repay, leaving them strapped with debt after leaving college. This study examines the potential role of assets and savings for promoting college progress among young adults. Overall, findings suggest that policies, such as Child Development Accounts (CDAs), that help parents and youth accumulate savings - especially savings for college - may increase college attendance and graduation completion rates.

The American Dream can be thought of as the belief that all Americans should be able to achieve economic mobility through their exercise of effort and ability. The public education system continues to be a key instrument for making the Dream a reality (Hochschild and Scovronick 2003). However, it is well recognized that attendance and graduation rates vary by socioeconomic status (Brown et al. 2009). For example, nearly 72 percent of high-income youth versus 50 percent of low-income youth who have recently graduated from high school attend college (College Board 2007a). Similarly, 78 percent of high-income youth versus 62 percent of low-income youth graduate from a four-year college (College Board 2007a). ${ }^{1}$

Child Development Accounts (CDAs) have been proposed as a potentially novel and promising mechanism for financing college (Boshara 2003; Sherraden 1991). An example of a CDA policy is the America Saving for Personal Investment, Retirement, and Education (ASPIRE) Act. ASPIRE would create

Electronically published March 15, 2011

American Journal of Education 117 (May 2011)

(C) 2011 by The University of Chicago. All rights reserved.

0195-6744/2011/11703-0002\$10.00 


\section{Staying on Course}

"KIDS Accounts," or a savings account for every newborn, with an initial $\$ 500$ deposit, along with opportunities for financial education. ${ }^{2}$ Children living in households with incomes below the national median would be eligible for an additional contribution of up to $\$ 500$ at birth and a savings incentive of $\$ 500$ per year in matching funds for amounts saved in accounts. When account holders turn 18, they would be permitted to make tax-free withdrawals for costs associated with postsecondary education, first-time home purchase, and retirement security.

Since youth's savings policies like the ASPIRE Act require youth and their families to save for their own education, they align well with the American value of personal responsibility and the belief that youth are the primary beneficiaries of higher education. However, it is desirable to conduct advance tests of large-scale youth's savings policies like the ASPIRE Act prior to passing them into legislation. Given this, in this study we first ask, Are net worth, parents' savings for youth, and youth's school savings significantly related to college progress? Second, we ask, Do youth's college expectations mediate the relationships between net worth, parents' savings for youth and youth's school savings and college progress? Third, we ask, Is there evidence to suggest that youth's school savings is more closely associated with educational outcomes than either net worth or parents' savings for youth?

The remainder of this study is broken up into five sections. The first section provides a rationale for why policy makers and educators should care about assets. The second section discusses existing research on assets, college attendance, college completion, and college expectations. In the third section, we discuss method. We report results and summarize results in the fourth section. In the final section, we interpret findings in the context of existing literature; identify limitations, research implications, and policy implications; and make concluding remarks.

\section{Why Should Policy Makers and Educators Care about Assets?}

A well-recognized barrier to college access and completion are high college costs. In recent years, the federal government has increasingly relied on policies that address short-term credit constraints by making loans more accessible to youth and their families (e.g., Federal Stafford and PLUS loan programs). However,

William ElLiotT is an assistant professor in the School of Social Work at the University of Pittsburgh and a faculty associate for both the Center for Social Development and the Center for Race and Social Problems. SONDRA BeverLy is a senior scholar at the Center for Social Development at Washington University in St. Louis. 
emphasis on loans has led to a growing number of youth leaving college burdened with high amounts of debt. High debt reduces the return on college for student borrowers who have left college. Equally important, high debt may negatively affect the subjective calculation youth make about attending college and completing college when they see and hear the stories of family and friends strapped with college debt. In this sense high college costs have both direct effects - they reduce access to college and the ability to complete college among college-age youth - and indirect effects - they dampen the expectations of youth who are not yet of college age. Policies that promote asset accumulation among youth and their parents may be an alternative to the current policy of debt accumulation. In the remainder of this section, we lay out this line of reasoning in greater detail for why asset accumulation is an alternative to debt accumulation.

\section{High Costs Result in High Unmet Need}

High college costs may make the education path to income mobility inaccessible for low- to moderate-income youth. The total cost of college attendance, which includes room and board, for an in-state student at a public four-year college for the 2007-8 school year was \$13,589 (College Board 2007b). This was an increase of 5.9 percent from the prior school year (College Board 2007b). The cost of a four-year private college also rose by 5.9 percent in 2007-08, up to $\$ 32,307$ (College Board 2007b). College choice researchers consistently find that rising college costs have a negative impact on college enrollment decisions (Heller 1997; Leslie and Brinkman 1988; McPherson and Schapiro 1998). For example, McPherson and Schapiro (1998) estimate that a $\$ 150$ net cost increase (in 1993-94 dollars) results in a 1.6 percentage point reduction in enrollment among low-income students.

However, it should be noted that because of financial aid many youth are not charged the list price (see, e.g., Hill et al. 2004). Despite this fact, even after financial aid, family contribution, work-study, and loans are considered, youth still face significant amounts of unmet need. According to the 2002 Advisory Committee on Student Financial Assistance (ACSFA), a group charged by Congress with enhancing access to postsecondary education for low-income youth, unmet need is "the portion of college expense not covered by the expected family contribution and student aid, including work-study and loans" (Advisory Committee on Student Financial Assistance 2002, 5). Oliver and Shapiro (2006) suggest that the high unmet need for college is largely the result of low asset accumulation. According to ACSFA (2002), lowincome youth on average face an unmet need of $\$ 3,800$ per year at four-year public colleges and $\$ 6,200$ at four-year private colleges. ${ }^{3}$ They estimate that financial barriers prevent 48 percent of college-qualified, low-income youth 


\section{Staying on Course}

and 43 percent of college-qualified, moderate-income youth from attending a four-year college (Advisory Committee on Student Financial Assistance 2002).

Not only do youth face barriers to college attendance and completion due to high costs and unmet need but also after they leave college many are burdened by heavy loan debts. We next explore the implications of the increasing reliance on loans for financing college - the shift toward a studentbased financial aid model.

\section{Debt Accumulation}

The belief in personal responsibility, and in students as the primary beneficiaries of higher education, has led to a student-based financial aid model in America (Baum 1996; Heller and Rogers 2006). This model suggests that each generation has to borrow to finance its' own education. In the 2008-9 school year, 45 percent of all financial aid received came from federal loans (College Board 2009). Moreover, from 2007-8 to 2008-9 total education borrowing increased by 5 percent or $\$ 4$ billion. ${ }^{4}$ Due to the current financial aid system's emphasis on loans as a socially acceptable way to finance college, students are incurring higher levels of debt upon leaving college. For example, the median loan debt of a graduate recipient from a four-year public college in 2007-8 was $\$ 17,700$, up 5 percent from 2003-4 (Steele and Baum 2009). Moreover, 10 percent of graduate recipients in 2007-8 had more than $\$ 40,000$ worth of debt (Steele and Baum 2009). At a four-year private college, the median loan debt of a graduate recipient was $\$ 22,375$ in 2007-8, up 4 percent from 2003-4. Among graduate recipients at a four-year private college, 22 percent have more than $\$ 40,000$ worth of debt (Steele and Baum 2009).

As a result of the increasing debt student borrowers' face, some policy makers and researchers question whether promoting college attendance and completion through debt accumulation (i.e., loans) is a wise policy decision (see, e.g., Baum 1996). As an alternative to debt accumulation, a growing number of policy makers and researchers are beginning to examine the effectiveness of asset accumulation strategies for promoting college attendance and completion among youth. We next discuss the potential of asset accumulation, particularly among youth, to serve as an alternative approach.

\section{Asset Accumulation as an Alternative}

Youth's savings is not a new topic. Savings programs intended for young people have been around as early as the late 1800s through school-based initiatives, 
such as the School Savings Banking in New York Public Schools (Cruce 2001). Since that time, opportunities for financial education and savings have expanded (Cruce 2002). Currently, a wide range of public and private initiatives support savings for young people (American Bankers Association 2009; Council for Economic Education 2010; Junior Achievement 2009; Young Americans Center for Financial Education 2010). For instance, the Young Americans Center for Financial Education, based in Denver, Colorado, provides a range of services, including financial summer camps, weekend activities, and even a bank designed specifically for young people ages 21 and younger (Young Americans Center for Financial Education 2010). The Young Americans Bank serves approximately 15,000 young people nationwide and offers the same types of services as a typical bank, such as checking and savings accounts, loans, and credit card services (Cline 2005; Young Americans Bank 2011; Young Americans Center for Financial Education 2010).

\section{Existing Research}

\section{Research on College Access}

Researchers have identified a number of factors, including social capital (Porfeli et al. 2009), human capital (Paulsen 2001), and economic capital (Coleman 1988), as being key predictors of college attendance and completion. Social capital is most commonly defined as the advantages that are embedded in social relationships (Coleman 1988). According to Coleman (1988), social capital comes in three forms: (a) unspoken obligations and expectations, $(b)$ information channels, and $(c)$ norms and sanctions. Research suggests that information forms may be a particularly important type of social capital for understanding college enrollment gaps (O'Connor et al. 2010). From this perspective, the amount of access parents have to information about college and how to pay for it is a critical factor for explaining gaps in college attendance. For example, O'Connor et al. (2010) include four indicators of financial knowledge: parents' actions to find out about financial aid, student's actions to find out about financial aid, whether parents saved money for their child's higher education, and whether parents indicated that it required too much work to apply for financial aid. Both parents' actions to find out about financial aid and children's actions to find out about financial aid are statistically significant predictors of enrollment in a four-year college versus a two-year college.

Human capital is commonly defined as the skills, capabilities, knowledge, and adaptive behaviors that an individual accumulates through education, work, and other life experiences (Sunstein 1997). According to Paulsen (2001), the relationship between human capital and college attendance is based on 


\section{Staying on Course}

an economic model that weighs benefits and costs in a rational decision-making process. For example, an individual may make the decision to enroll in college if he or she perceives that the benefit exceeds the cost of attending (Paulsen 2001). The perception of benefits and costs is based on information the young adult has before enrollment. According to Stratton et al. (2007), one of the most effective pieces of information young adults have is their academic performance as reflected by high school grades or standardized test scores. Given this, youth's academic achievement is often used as a proxy for human capital. From this perspective, youth's ability, as well as previous investments in human capital, will positively influence future earnings to the extent that these factors interact with additional human capital investments to increase the productivity of youth.

The role of economic capital, typically defined as family income, has long been established as having a positive impact on educational outcomes (BrooksGunn and Duncan 1997; Coleman et al. 1966; Yeung et al. 2002). According to Sirin (2005), it is perhaps the most widely applied contextual variable in research on education. Research shows that, as family resources available to youth increase, the educational performance, high school graduation, and college attendance rates of youth improve (Coleman et al. 1966). However, it is not merely the amount of the resources but also the diversity of the resources that lead to greater academic achievement. As Coleman et al. (1966) posit, youth from families of higher socioeconomic status (SES) do better because they are exposed to a wider set of resources that they can tap into to promote learning. However, until recently this research has largely ignored assets as a type of financial resource with independent effects from income (Oliver and Shapiro 2006; Sherraden 1991).

While education research has given considerable attention to income, assets are often excluded, particularly youth's assets, as a key variable in operationalizing economic capital in the research on college attendance and graduation. In this study we include assets (net worth, parents' savings, and adolescents' savings) as a separate measure of economic capital. Next, we review research on the assets/college attendance and assets/college completion relationships. Then, we review research on the assets/college expectations relationship.

\section{Research on Assets and College Attendance}

We find nine studies that examine the relationship between assets and college attendance (Charles et al. 2007; Conley 2001; Destin 2009; Elliott and Beverly, forthcoming; Haveman and Wolff 2005; Huang et al. 2010; Jez 2008; Nam and Huang 2009; Williams-Shanks and Destin 2009). All but two (Charles et al. 2007; Jez 2008) of the nine studies use data from the Panel Study of Income 
Dynamics (PSID) and its supplements. Charles et al. (2007) uses data from the National Education Longitudinal Study (NELS:88), and Jez (2008) uses data from the National Longitudinal Study of Youth (NLSY) 1997. Most of the research (eight out of the nine studies) on assets and college attendance focuses on net worth. Net worth is total family assets minus debt. Findings are mixed in regards to net worth. Conley (2001), Destin (2009), WilliamsShanks and Destin (2009), and Haveman and Wilson (2007) find that net worth is positively related to college attendance. Jez (2008), Nam and Huang (2009), and Elliott and Beverly (forthcoming) find that net worth is not significantly related to college attendance. Huang et al.'s (2010) study finds mixed results with respect to net worth. Huang et al. estimate a series of structural equation models (SEM) to examine whether asset effects on college attendance are short term (i.e., borrowing constraints around the time of college entry are a deciding factor) and/or long term (i.e., early investment in youth helps them to be prepared to attend college later in life). In the case of net worth, there is evidence that net worth has short-term effects but not long-term effects.

It appears that findings are sensitive to the inclusion of youth's academic achievement or cognitive ability. Studies that find that net worth is significant typically do not control for academic achievement or ability (Conley 2001; Destin 2009; Williams-Shanks and Destin 2009). All of the studies with insignificant results for net worth control for achievement or ability (Elliott and Beverly, forthcoming; Jez 2008; Nam and Huang 2009). Elliott and Beverly (forthcoming) add net worth to the model after academic achievement, and so the independent effects of academic achievement cannot be determined. However, Jez (2008) finds that net worth is significant in the basic model but is not significant once academic achievement is added to the model. Similarly, Nam and Huang (2009) find that net worth is significant until they add cognitive ability (i.e., whether adolescents were ever in a gifted program or ever repeated a grade).

Two studies include parents' savings (Charles et al. 2007; Elliott and Beverly, forthcoming). Charles et al. (2007) find that whether or not parents have savings for youth's college expenses is positively related to attendance at both two-year and four-year colleges, while the amount of school savings is positively related only to four-year college attendance. This study does not control for academic achievement or cognitive ability. Elliott and Beverly (forthcoming) also include parents' savings for youth. They find that it does not have a significant association with college attendance when controlling for academic achievement.

In the only study to test youth's savings and college attendance, Elliott and Beverly (forthcoming) find that youth's savings is positively related to college attendance. This study used a sample of youth who expected to graduate from 


\section{Staying on Course}

college, while controlling for academic achievement (i.e., a combined reading and math score).

\section{Research on Assets and College Graduation}

Six studies examine the association between assets and college graduation (Conley 1999, 2001; Haveman and Wilson 2007; Nam and Huang 2009; Zhan and Sherraden 2009, 2010). Zhan and Sherraden (2009, 2010) use NLSY79 data, while the other studies use PSID data.

All but one of these studies find that assets are significantly related to college graduation. Among young adults ages 18-20, Conley (1999) finds that net worth is positively related to college graduation. In a later study of young adults ages 22-30, Conley (2001) finds that the relationship between net worth and college graduation is significant but that it is so at $p<.10$. Haveman and Wilson (2007) find that net worth is significantly related to college graduation for 25-year-olds and 29-year-olds. Zhan and Sherraden (2009) examine the effects of assets on college graduation for young adults ages 23-26. They find that both liquid assets (e.g., savings, stocks, and bonds) and nonliquid assets (e.g., a home or business) are significantly related to college graduation. In a more recent study of young adults ages 23-26, Zhan and Sherraden (2010) find that liquid assets are positively related to college graduation for whites while nonliquid assets are positively related to college graduation for blacks.

Nam and Huang's (2009) study is the only one to find that neither net worth nor liquid assets are significantly associated with college graduation. This may be because theirs is the only study testing college graduation to include proxies for young adults' cognitive ability (i.e., whether they were ever in a gifted class or ever repeated a grade). In contrast, they find that income is significant.

\section{Research on College Expectations as a Mediator}

We find five studies that test whether college expectations mediate the relationships between assets and youth's educational outcomes (Elliott 2009; Grinstein-Weiss et al. 2009; Zhan 2006; Zhan and Sherraden 2003, 2009). All of these studies use the Baron and Kenny (1986) method of testing for mediation. In addition, Elliott (2009) uses bootstrapping (Bollen and Stine 1992; Preacher and Hayes 2004) and the Sobel (1982) test of indirect effects.

In a sample of youth ages 12-18, Elliott (2009) finds that youth's college expectations act as a partial mediator between their own savings and their math achievement. Using a sample of single mothers, Zhan and Sherraden 
(2003) find that mothers' college expectations for their children partially mediate both the relationship between mothers' savings and whether youth graduate from high school and the relationship between homeownership and youth's grades. They suggest that two-way causation may be present; that is, assets may affect attitudes, and attitudes may also affect asset accumulation. In a sample of youth ages 5-17, Grinstein-Weiss et al. (2009) find that parents' college expectations partially mediate the relationship between total household assets and youth's school outcomes (having ever repeated a grade, having ever been expelled or suspended, and interest in schoolwork). In a sample of youth ages 7-14, Zhan (2006) also finds that mothers' expectations partially mediate the relationship between net worth and youth's performance in math and reading.

In the only study that does not find evidence of mediation, Zhan and Sherraden (2009) examine the indirect association of parents' assets on college completion through both parents' and youth's college expectations. They find evidence that financial assets are positively related to parents' and youth's college expectations but little evidence of mediation. This is the only study to test for mediation between assets and college completion; other studies examine earlier educational outcomes.

\section{Summary of Existing Research}

In sum, a growing body of research examines the relationship between different forms of assets and college attendance or completion. Most of the research focuses on household assets, especially net worth. Findings appear to be sensitive to the inclusion of youth's academic achievement or cognitive ability. Studies that control for achievement or ability have consistently found that net worth is not related to attendance. Most of the research on college completion finds that assets are positively related to completion. However, the one study that controls for ability finds that net worth and liquid assets are not significant. Only one study examines the effect of youth's savings on college attendance, and it uses a sample of youth who expect to graduate from college.

Finally, research suggests that the effects of assets and savings on educational outcomes may be mediated by parents' or youth's college expectations. However, no study looks at youth's college expectations as a mediator of the relationship between youth's school savings and college attendance. Further, most studies have relied on the Baron and Kenny (1986) method for testing mediation, but this may not be the most rigorous method (Preacher and Hayes 2004).

This study uses longitudinal data to examine the effects of savings and assets on young adults' college progress. Unlike previous studies, this study includes a 


\section{Staying on Course}

measure of youth's school savings. In addition to conducting descriptive analyses, logistic regression is used to identify the independent effects of assets while controlling for a number of parent and youth characteristics, including youth's academic achievement. Finally, this study examines whether youth's college expectations mediate the relationships between assets and college progress using both the Baron and Kenny (1986) method and bootstrapping (Preacher and Hayes 2004).

More specifically, in this study we ask: (1) Are net worth, parents' school savings for youth, and youth's school savings significantly related to college progress? (2) Do youthcollege expectations mediate the relationships between net worth, parents' school savings for youth, and youth's school savings and college progress? (3) Is there evidence to suggest that youth's school savings is more closely associated with educational outcomes than either net worth or parents' school savings for youth?

\section{Method}

\section{Data}

This study uses longitudinal data from the PSID and its supplements, the Child Development Supplement (CDS) and the Transition into Adulthood supplement (TA). The PSID is a nationally representative longitudinal survey of U.S. individuals and families that began in 1968. The PSID collects data on such things as employment, income, and assets. Our independent variables related to households and parents are taken from 1999, 2001, and 2002 PSID data.

The CDS was administered to 3,563 PSID respondents in 1997 to collect a wide range of data on parents and their children ages birth to 12 years. Questions cover a broad range of developmental outcomes across the domains of health, psychological well-being, social relationships, cognitive development, achievement, motivation, and education. Follow-up surveys were administered in 2002 and 2007. For this study, independent variables for young adults are taken from the 2002 CDS because this is the first year data were collected on parents' school savings for youth and youth's school savings. Age 12 is the first year that youth were asked questions about savings and college expectations. The TA supplement, administered in 2005 and 2007, measures outcomes for young adults who participated in earlier waves of the CDS and are no longer in high school. Our outcome variables are taken from the 2007 TA.

The three data sets are linked using PSID, CDS, and TA map files containing family and personal ID numbers. The linked data sets provide a rich 


\section{Elliott and Beverly}

opportunity for analyses in which data collected at one point in time (2001 or earlier) can be used to predict outcomes at a later point in time (2007) and stable background characteristics can be used as covariates. Because the PSID initially oversampled low-income families, both the descriptive and multivariate analyses are weighted using the last observed weight variable, as recommended by the PSID manual (Gouskova 2001).

\section{Variables}

Assets.-Three different types of assets are examined: net worth, parents' savings for youth, and youth's school savings.

Net worth: Net worth in the PSID is a continuous variable that sums separate household values for business, checking, or savings accounts; real estate; and stocks and other assets and then subtracts out credit card and other debt. In this analysis, net worth does not include home equity. Net worth is averaged for 1994, 1999, and 2001; each year of net worth is inflated to 2002 price levels. Because net worth is positively skewed, the log form of net worth is used for regression analyses. Since some individuals have a negative value on the net worth variable, it has been necessary to make adjustments to these numbers so that the natural log of net worth can be calculated. All net worth values that are less than or equal to zero are recoded as one so that the natural log can be ascertained (e.g., Henretta and Campbell 1978; Orr 2003). In descriptive analysis, we use a trichotomous net worth variable with the following categories: negative net worth $(<\$ 0)$, modest net worth $(\$ 0-\$ 10,000)$, and high net worth $(>\$ 10,000) .{ }^{5}$ High net worth households serve as the reference group.

Parents' school savings for youth: Heads of households are asked in 2002 whether they (or another caregiver) have any money put aside specifically for their youth's college or future schooling that is separate from other types of savings they may have had for him or her. The parents' school savings variable divided youth into two categories: (1) those who in 2002 had school savings for their youth and (2) those with no school savings for their youth.

Youth school savings: In this study we focus on savings youth have designated specifically for school instead of savings that can be used for any purpose. We suggest because it has been mentally designated by the youth for school, it is more likely to be predictive of school outcomes because the link between saving and school is clearer. Specifically, youth are asked in 2002 whether they have a savings or bank account in their name. If they have an account, they are also asked whether they have designated a portion of this savings for future school, like college. The youth's school savings variable divides youth into two categories: (1) those who in 2002 had an account and had designated a 
portion of the savings in the account for school and (2) those with who had no account and those who had an account but had not designated a portion of the savings in the account for school.

Potential mediating variable. - College expectations are a dichotomous variable indicating whether young adults expect to graduate from a four-year college as youth. This variable is taken from the 2002 CDS, where youth are asked how likely they are to graduate from a four-year college. They could respond by saying no chance, some chance (about 50/50) pretty likely, or it will happen. Youth who chose either of the latter two responses are defined as "expecting to graduate."

Outcome variable. - The outcome variable used in this study is college progress. College progress indicates whether youth are "on course." Youth who are currently enrolled in or who have graduated from a two-year or four-year college are defined as on course. Those who are not currently enrolled and who do not have college degrees are defined as off course. ${ }^{6}$

Control variables. - There are eight control variables: family income, household size, head's education, head's marital status, and youth's race, youth's gender, youth's academic achievement, and youth's age in 2002. Family income is calculated by averaging family income for 1993, 1997, and 2002. Income averaged over multiple years provides the best estimate of "permanent income" (Blau 1999; Mayer 1997). Income is inflated to 2002 price levels using the Consumer Price Index for 1993 and 1997. Because family income is positively skewed, the log of family income is used in regression analyses. In descriptive analyses, we use a trichotomous variable with the following categories: low income $(<\$ 33,377)$, modest income $(\$ 33,377-\$ 84,015)$, and high income $\left(\$ 84,016\right.$ or more). ${ }^{7}$

Household size, head's marital status, and head's education all came from the 2001 PSID. Household size is a continuous variable. Head's marital status is a categorical variable (married or unmarried). Head's education is a continuous variable (1-16), with each number representing a year of completed schooling. We also use a categorical variable, dividing heads into three groups: those with a high school degree or less, those with some college, and those with a four-year degree or more. Youth's race (white or black), youth's gender (male or female), youth's age, and youth's academic achievement come from 2002 CDS data. Academic achievement is a continuous variable, a combination of math and reading scores. The Woodcock Johnson Psycho-Educational Battery (WJ-R), a well-respected measure, is used by the CDS to assess math and reading ability (Mainieri 2006). In descriptive analysis, we use a dichotomous variable indicating whether youth have average or above-average achievement or below-average achievement. Age in 2002 is a continuous variable. In the descriptive analysis, we use a dichotomous variable indicating whether a youth was below age 16 or age 16 or older in 2002 . 


\section{Missing Data}

Prior to running logistic regressions, school savings are analyzed to determine if missing data are missing completely at random (MCAR). According to Little and Ruin (1987), data are MCAR when, given the observed data, the missingness mechanism does not depend on the unobserved data. To test for differences between excluded cases and cases included, all missing variables are transformed to a miss variable and chi square and $t$-tests are run. There are no statistically significant differences between the cases in regards to college progress. List-wise deletion is used to eliminate cases with missing data.

\section{Study Sample}

The 2007 TA sample consisted of 1,118 participants. The sample in this study is restricted to black and white youth because only small numbers of other racial groups exist in the TA. Our final weighted sample of 1,003 youth includes 795 whites and 208 blacks. Youth age in 2002 ranges from 12 to 19 $($ mean $=16, \mathrm{SD}=1.54)$. Youth age in 2007 ranges from 17 to 23 (mean $=$ $20, \mathrm{SD}=1.6) \cdot{ }^{8}$ Household size ranges from 2 to 11 (mean $=4.2, \mathrm{SD}=$ 1.2). Academic achievement ranges from 138 to 339 (mean $=213, \mathrm{SD}=$ 33.0). Other sample characteristics are summarized in table 1.

\section{Analysis Plan}

This study uses simple frequencies and logistic regressions as the primary analytic tools. However, in the case of survey data, common SAS syntax for analyzing descriptive data may not be appropriate (SAS Institute 2008). To account for the survey design of the PSID, SURVEYFREQ is used to determine the percentage of youth on course (SAS Institute 2008). Multivariate analyses are used to examine the independent effects of assets on college progress using PROC SURVEYLOGISTIC (SAS Institute 2008). Because a small portion of the households have more than one young adult, standard errors are clustered into the same family unit with the CLUSTER statement (SAS Institute 2008). Moreover, we provide measures of predictive accuracy through the maximum rescaled $R^{2}$ (not equivalent to the variance explained in a multiple regression model but closer to one is also positive) and classification tables. The cutoff for the classification tables is 0.5.

Additional regressions are estimated to test for mediation using the Baron and Kenny (1986) method. A mediating variable is a variable that helps explain the relationship between an independent and dependent variable. Mediation 
occurs when an independent variable has an indirect effect on a dependent variable, that is, when an independent variable influences a mediator, which in turn influences a dependent variable (Baron and Kenny 1986). This study examines whether youth's college expectations mediate the relationship between each asset variable and college progress.

According to the Baron and Kenny (1986) method, statistical evidence of mediation can be established using a series of linear regressions testing whether (a) the independent variable is related to the outcome variable, $(b)$ the independent variable is related to the proposed mediator, and $(c)$ the mediator is related to the outcome in a model controlling for the effects of the independent variable. If the independent variable is related to the outcome variable and the proposed mediator, and if the association between the independent variable and the outcome variable is reduced (or eliminated) when the proposed mediator is included in the model, then there is evidence of mediation.

Three regressions are presented. Model 1 estimates the effects of assets (log of net worth, parent savings, and youth's school savings) on college progress. Model 2 estimates the effects of assets on college expectations. Model 3 estimates the effects of assets on college progress, while controlling for expectations, and the effects of expectations on college progress, while controlling for assets. Comparing models 1 and 3 shows the effects of adding expectations to the main regression model. If the association between an asset variable and college progress is reduced when expectations are added, there is evidence that the effect of that asset variable partially operates through expectations (Baron and Kenny 1986).

However, some scholars claim that the Baron and Kenny (1986) test is unable to detect these more broadly defined indirect effects (e.g., Mathieu and Taylor 2006; Preacher and Hayes 2004). Confounding, suppression, and interactive effects could mitigate any overall effects that the independent variable has on the dependent variable (Mathieu and Taylor 2006). This can cause researchers to erroneously conclude that there are or are not indirect effects. Therefore, scholars increasingly suggest using a direct test of indirect effects such as bootstrapping (Bollen and Stine 1992; MacKinnon et al. 2004; Mathieu and Taylor 2006; Preacher and Hayes 2004). An indirect effect exists when an asset is associated with youth's college expectations and expectations are associated with college progress - even if the asset is not significantly related to college progress. In this case, expectations do not account for any portion of the relationship between the asset and college progress because there is no relationship between those two variables.

We use bootstrapping to test for indirect effects. Bootstrapping is a nonparametric approach to effect size estimation and hypothesis testing (Mooney and Duval 1993). Bootstrapping does not make assumptions about the shape of the distribution of the variables or the sampling distribution of the statistic (Mooney 
and Duval 1993). Shrout and Bolger (2002) suggest that bootstrapping is a way of circumventing the power problem introduced by asymmetries and other forms of nonnormality in the sampling distribution of the indirect effect. Bootstrapping is accomplished by taking a large number of samples of size $n$ (where $n$ is the original sample size) from the data, sampling with replacement, and computing the indirect effect in each sample (Preacher and Hayes 2004). In this study, 4,000 replications are performed.

\section{Results}

\section{Descriptive Results}

Table 1 shows the percentage of young adults who are enrolled in or have graduated from a two-year college, a four-year college, or a graduate program soon after high school. An estimated 57 percent of young adults are on course. Young adults who lived in high-income households (82 percent), whites (64 percent), females (62 percent), young adults with above-average achievement (78 percent), and young adults who lived in the most educated households (84 percent) are more likely to be on course. Also, young adults who expected to graduate from college (71 percent) are more likely to be on course.

Assets appear to matter. About 69 percent of young adults who lived in high net worth households as youth are on course, as compared to 41 percent of young adults who lived in modest net worth households and 35 percent of young adults who lived in negative net worth households. About 77 percent of young adults who live with parents who have school savings for them are on course. In comparison, only 54 percent of young adults who live with parents who do not have savings for them are on course. Finally, 75 percent of young adults who have some of their own savings designated for school are on course, as compared to 45 percent of young adults without school savings.

In sum, the overall pattern for young adults just out of high school is that those who are white and those who have lived in more educated, higherincome, and wealthier households as youth are more likely to be on course. Young adults with household assets and young adults who have school savings of their own are also more likely than others to be on course.

\section{Logistic Regression Results}

A correlation matrix of the independent variables is provided in appendix table A1. To conserve space, only the full logistic regression model is reported in this 
Staying on Course

TABLE 1

Characteristics of the Study Sample and Percent on Course

\begin{tabular}{|c|c|c|}
\hline & Percent & Percent on Course \\
\hline Full sample & 100 & 57 \\
\hline \multicolumn{3}{|l|}{ Controls: } \\
\hline Below age 16 in 2002 & 59 & 57 \\
\hline Age 16 or older in 2002 & 41 & 58 \\
\hline White & 79 & 64 \\
\hline Black & 21 & 35 \\
\hline Male & 50 & 54 \\
\hline Female & 50 & 62 \\
\hline Average or above academic achievement & 36 & 78 \\
\hline Below-average academic achievement & 64 & 44 \\
\hline Married head & 74 & 66 \\
\hline Unmarried head & 26 & 37 \\
\hline Head has four-year degree or more & 28 & 84 \\
\hline Head has some college & 23 & 58 \\
\hline Head has high school degree or less & 49 & 42 \\
\hline High-income $(>\$ 84,016)$ & 32 & 82 \\
\hline Moderate-income $(\$ 33,377-\$ 84,016)$ & 41 & 54 \\
\hline Low-income $(<\$ 33,377)$ & 27 & 36 \\
\hline \multicolumn{3}{|l|}{ Asset variables: } \\
\hline High net worth $(>\$ 10,000)$ & 62 & 69 \\
\hline Modest net worth $(\$ 0-\$ 10,000)$ & 21 & 41 \\
\hline Negative net worth $(<\$ 0)$ & 16 & 35 \\
\hline Parents' school savings & 21 & 77 \\
\hline No parents' school savings & 79 & 54 \\
\hline Youth's school savings & 46 & 75 \\
\hline No youth's school savings & 54 & 45 \\
\hline \multicolumn{3}{|l|}{ Potential mediator: } \\
\hline Expected to graduate from college & 71 & 71 \\
\hline Did not expect to graduate from college & 29 & 29 \\
\hline
\end{tabular}

Source.-Weighted data from the Panel Study of Income Dynamics and its supplements.

NoTE.- The sample includes 1,003 young adults aged 17-23 and not in high school in 2007. "On course" includes young adults who are currently enrolled in or have a degree from a two-year college, a four-year college, or a graduate program.

section - model 3. Table 2 provides information on the models with and without children's expectations - models 1 and 2.

Model 3 estimates the independent effects of assets on college progress while controlling for demographic variables and academic achievement as well as youth's college expectations (table 2). Approximately 47 percent of the variance in college progress is explained. With a cutoff of 0.5 , the classification table indicates that the model correctly predicts 74.8 percent of the cases. The accuracy of the prediction for young adults being on course (sensitivity $=75.2$ percent) and young 


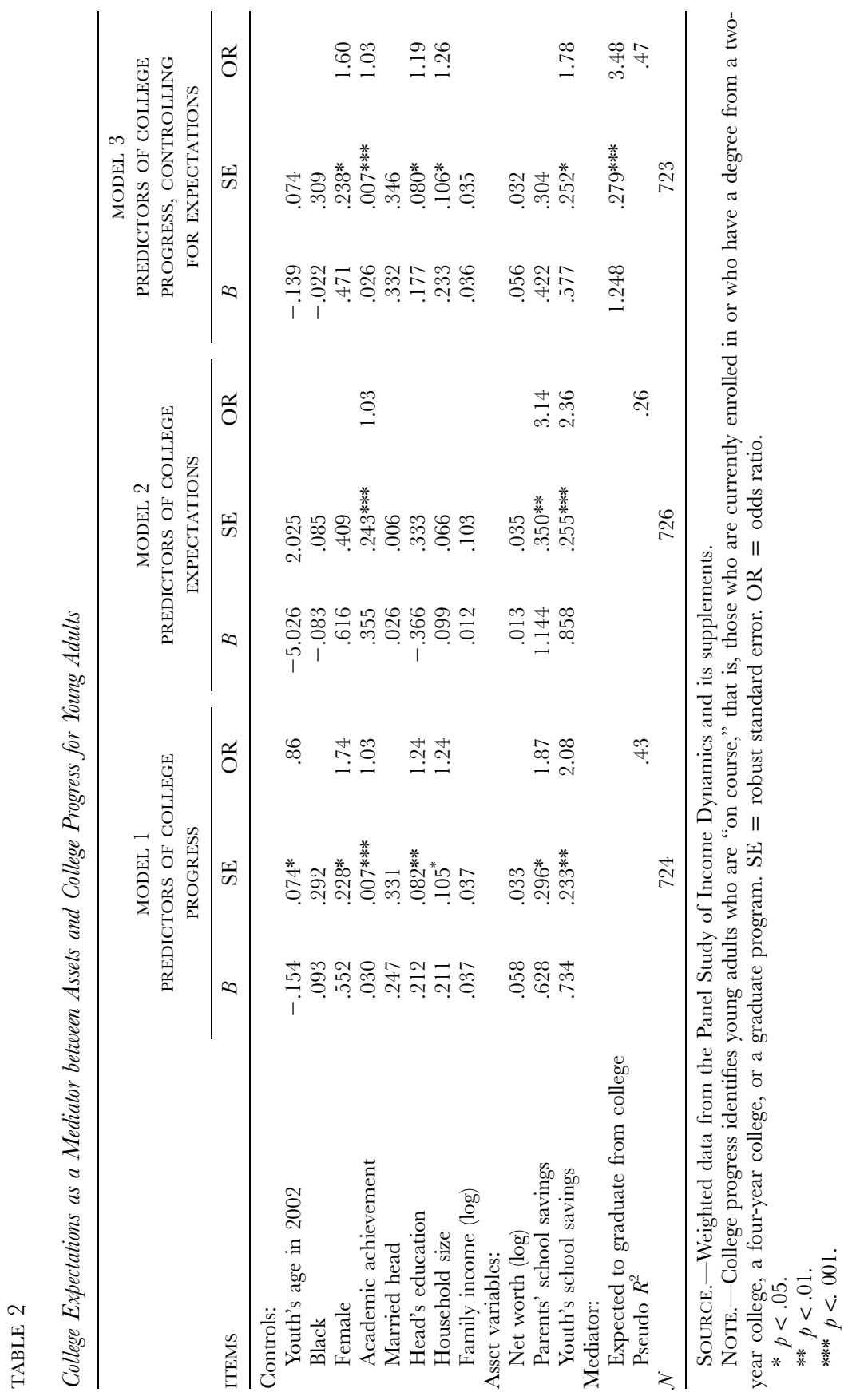




\section{Staying on Course}

adults being off course (specificity $=74.4$ ) is roughly the same. Gender, academic achievement, head's education, household size, youth's school savings, and expectations are significantly associated with college progress. Girls are more than one and a half times as likely as boys to be on course (odds ratio $=1.60, p=$ $.04)$. For each one point increase in academic achievement, the odds of being on course increase by 3 percent (odds ratio $=1.03, p=.0003$ ). For each one year increase in head's education, the odds of being on course increase by 19 percent (odds ratio $=1.19, p=.03$ ). For each one point increase in household size, the odds of being on course increase by 26 percent (odds ratio $=1.26, p=.03$ ). Young adults who have accounts and who have designated some savings for school are almost twice as likely to be on course as those who have no accounts or who have accounts but have not designated some savings for school (odds ratio $=$ $1.72, p=.02$ ). Young adults who expect to graduate from college are nearly four times more likely to be on course than young adults who do not (odds ratio $=$ $3.48, p<.0001)$.

\section{Testing Mediation with the Baron and Kenny Method}

Net worth is not significantly related to college progress (model 1), so there is no need to examine whether college expectations mediate this relationship according to Baron and Kenny (1986). The Baron and Kenny (1986) test does provide evidence that college expectations partially mediate the relationship between parents' school savings and college progress and youth's school savings and college progress in young adulthood. First, parents' school savings and youth's school savings are significantly related to college progress (model 1). Second, parents' school savings and youth's school savings are significantly related to college expectations (model 2). Third, in the case of parents' school savings, comparing model 1 to model 3 reveals that parent expectations are no longer significant when expectations are added to the model. This suggests that expectations act as a complete mediator between parents' school savings and college progress. In the case of youth's school savings, comparing model 1 to model 3 reveals a modest drop in the association between youth's school savings and college progress when expectations are added to the model. This suggests that expectations act as a partial mediator between youth's school savings and college progress.

\section{Testing Indirect Effects with Bootstrapping}

Bootstrapping is used as a direct test of indirect effects. Like the Baron and Kenny (1986) test, bootstrapping provides evidence that youth's college expectations carry the effect of parents' school savings onto college progress. 
The true indirect effect is estimated to lie between .05 and .12 with 99 percent confidence. Because zero is not in the 99 percent confidence interval, one can conclude that the indirect effect is significantly different from zero at $p<.05$ (two tailed). Similarly, bootstrapping provides evidence that youth's college expectations carry the effect of youth's school savings onto college progress. The true indirect effect is estimated to lie between .04 and .10 with 99 percent confidence. Because zero is not in the 99 percent confidence interval, one can conclude that the indirect effect is significantly different from zero at $p<.05$ (two tailed). We do not use bootstrapping to test whether net worth has indirect effects on college progress because net worth is not significantly related to expectations in model 2.

\section{Summary}

Consistent with our first hypothesis, parents' school savings and youth's school savings have a positive, strong, and significant association with college progress soon after high school. Contrary to the first hypothesis, net worth is not significantly associated with college progress. Parent's school savings and youth's school savings are significantly associated with youth's college expectations when controlling for demographic and academic achievement variables. Net worth is not significantly related to college expectations. That youth's school savings has a significant association with college progress and net worth even after controlling for expectations and parents' school savings does not may provide some support for our second hypothesis, that youth's school savings has especially powerful effects on young adult's college progress.

The Baron and Kenny (1986) test produced mixed results regarding mediation. According to this test, youth's college expectations partially mediate the relationship between youth's school savings and college progress but do not mediate the relationships between net worth and college progress. In the case of parents' school savings, youth's college expectations fully mediate its relationship with college progress. Bootstrapping confirms that expectations carry the effect of both parents' school savings and youth's school savings onto youth's college progress. It should also be noted that gender, academic achievement, head's education, household size, and youth's college expectations are significantly related to college progress; race and family income are not.

\section{Discussion and Conclusion}

Findings from this study suggest that almost 57 percent of young adults between the ages of 17 and 23 are on course in 2007. Thus, 43 percent are off course. 


\section{Staying on Course}

There are important race and class differences. Whites and young adults who lived in more educated, higher-income, and wealthier households as youth are more likely to be on course. Additionally, young adults of parents who have school savings for them as youth and young adults with savings of their own as youth are more likely to be on course.

In logistic regression analyses, academic achievement, college expectations, head's education, and household size have a strong positive association with college progress. This is consistent with previous research (e.g., Advisory Committee on Student Financial Assistance 2006; Elliott and Beverly, forthcoming). For asset variables, results are mixed. Youth's school savings has a powerful positive association with college progress. Young adults who as youth have school savings of their own are about two times more likely to be on course than those who do not. This is consistent with previous research on college attendance (Elliott and Beverly, forthcoming) demonstrating that youth's school savings is determined to have a strong association with college progress.

In addition, parents' savings for youth is significantly related to college progress. This finding is in line with research by Charles et al. (2007), who also find that parents' savings is significantly related to college attendance. However, these findings contradict findings by O'Connor et al. (2010). They find that parents' school savings is not significant. A reason for differences between studies may be that O'Connor et al. (2010) only include in their sample young adults who are college qualified.

In regards to net worth, we find that it is not significant. The finding that net worth is not significant is consistent with previous research that controls for youth's academic achievement or cognitive ability (Elliott and Beverly, forthcoming; Jez 2008; Nam and Huang 2009).

The second hypothesis, that youth's school savings has a stronger association with college progress than net worth or parents' school savings, is based on the theoretical proposition that having savings in one's own name may increase a young person's perceived control over financing college, which may in turn may lead to improved college progress. Support for this hypothesis is mixed. As stated above, while net worth did not have a significant association with college progress or youth's college expectations in this study, parents' school savings did.

More generally, correlational findings reported in appendix table Al indicate that youth's school savings has a significant but low correlation with variables typically used to measure youth's socioeconomic status (SES; i.e., parent's level of education and family income). This suggests that youth's school savings findings in this study is independent of traditional SES factors.

Further, in his seminal book Assets and the Poor, Sherraden (1991) suggests that assets may have indirect effects on people's outcomes, for example, through attitudinal changes. Findings from our study are mixed with respect 
to this general theoretical statement. Using more rigorous methods than have been used in the past, ${ }^{9}$ this study finds that the relationship between youth's school savings and college progress is partially mediated by youth's college expectations. These findings are consistent with previous research that finds that expectations (parents' and youth's) act as a mediator between assets and youth's educational outcomes (Elliott 2009; Zhan 2006; Zhan and Sherraden 2003).

In contrast, in the case of net worth, evidence does not suggest that this relationship works through college expectations. This finding is consistent with Zhan and Sherraden's (2010) finding that the effects of liquid and illiquid assets on college completion are not mediated by college expectations. Scholars in the asset field have argued that more research is needed on the mechanisms through which assets may bring about positive outcomes (Sherraden 2005; Schreiner and Sherraden 2007). Although it is unlikely that the effects of assets on educational outcomes always work through educational expectations, this study, combined with others, suggests that educational expectations can be an important mechanism for transmitting the positive effects of asset holding.

\section{Limitations}

A limitation of this study is the uncertainty of omitted variable bias. Young adults who have savings as youth may differ from other young adults in other ways that affect college progress (e.g., motivation or self-discipline). Thus, it could be that the significant effect of assets is spurious. This is dealt with, in part, by controlling for various factors that are commonly associated with college attendance and completion, including academic achievement, but this alternative explanation cannot be fully ruled out. It is also impossible in this study to measure whether youth grow up with knowledge that they have financial resources to help pay for current and future schooling. In this study, savings is only measured at a single point in time.

Another limitation is the mean age of youth, age 20 (59 percent of the youth are 20 or older). Although age 20 is old enough for young adults to attend and graduate from college, particularly a two-year college, most will take longer. Moreover, some may not attend for several years after high school, and some may start college at a young age but stop and then start again later. The percentage of young adults on course is therefore likely to increase over time. However, more 18-21-year-olds are enrolled in college than any other age group. Approximately 50 percent of young adults aged 18-21 are enrolled in college. In comparison, only about 30 percent of 22-24-year-olds are enrolled, and just over 10 percent of 25-29-year-olds are enrolled (Baum and Ma 2009). In addition, research consistently shows that older students are less 


\section{Staying on Course}

likely than younger students to graduate from college (Choy 2002). Therefore, if young adults do not attend college shortly after high school, the likelihood of ever attending or completing college is greatly reduced.

In the case of mediation, there is not temporal ordering. In order for temporal precedence to occur, assets must precede expectations and expectations must precede college progress. In this study, youth's savings and youth's expectations are both measured in 2002. Therefore, it cannot be determined from the findings, for example, whether assets cause expectations or expectations cause assets. It can only be determined that there is an association between assets and expectations.

Moreover, there is also potential measurement error in the school savings variable. Since there is a fairly large difference in age of youth in 2002 (1219), it could be that younger youth do not report designating their savings for school at similar rates as older youth. If this is true, findings related to youth's school savings may be driven by older youth. Younger youth may not be able to grasp the relationship between savings and a future opportunity such as attending college. Age 12 is the first year that the CDS asks youth if they have savings of their own. However, evidence from behavioral economics suggests that youth may benefit from saving as early as age 12 and that somewhere between the ages of 6 and 12, they begin to grasp the relationship between saving and future opportunity (see e.g., Elliott et al. 2010; SonugaBarke and Webley 1993). Moreover, we find that savings rates among youth below age 16 (23.0 percent) and youth age 16 or older (22.5 percent) are roughly equal. Therefore, it is unlikely that findings are being driven by differences in youth's age in 2002, the year youth's school savings is measured.

Finally, it is not claimed here that assets are the most important factor for understanding college progress. Assets appear to matter and are an understudied factor. More research is needed to determine the importance of assets for educational outcomes.

\section{Implications}

Consistent with previous research (e.g., Mau 1995), findings from this study indicate that youth's college expectations are a strong predictor of youth's educational outcomes. Given this, programs that seek to build expectations are likely to be effective at increasing the percentage of youth who remain on course shortly after leaving high school. Moreover, this study adds to our understanding of how expectations are formed. Previous research on youth's college expectations has largely ignored the role that parents' school savings and youth's school savings potentially play in the formation of youth's expectations. Findings from this study indicate that when parents have school 
savings for their children, youth are about three times more likely to expect to graduate from a four-year college and when youth have school savings of their own they are over three times as likely to expect to graduate from a four-year college.

Further, an important goal of this study was to conduct an advance test of large-scale youth's savings policies like the ASPIRE Act prior to passing them into legislation using the best available data. In particular, we wanted to test their ability to promote college progress. We find that youth with savings are approximately twice as likely to be on course as youth without savings. If our findings regarding youth's school savings are confirmed in future research, then policies that promote large-scale youth's savings policies may be an important part of a strategy to improve college progress.

Moreover, findings suggest that youth's school savings may be a way of reducing potential negative effects associated with accumulating college debt. The belief in personal responsibility and students as the primary beneficiaries of higher education has led to a student-based financial aid model in America that emphasizes loans over saving (Baum 1996; Heller and Rogers 2006). However, our findings suggest that even if youth may not be able to save large sums of money, they may still benefit from having school savings through its indirect effects on college progress through youth's expectations. This attitudinal effect of having savings could be as important as or more important than the money itself in affecting the transition from high school to college. So, whereas a model of financing college that relies on loans may negatively influence current and future generations of college goers' perceptions about the costs and benefits of college (Baum 1996), a model of financing college through youth's savings may positively influence their perceptions about the costs and benefits.

Another implication of this study is that children as young as age 12 are able to make a link between saving and college. This is an important question because it provides some insight into when youth's savings' programs may be most likely to create attitudinal changes in youth. If youth are not able to understand that savings can be used to help pay for college, we would expect that younger youth will be less likely to designate savings for college than older youth. Further, if younger youth are less likely to designate savings for college, than the finding that youth's school savings may help to change youth expectations may be being driven by older youth. However, we find that youth between the ages of 12 and 15 are equally likely to have designated some portion of their savings for school purposes as youth who are between the ages of 16 and 19 (approximately 23 percent for each age group). Therefore, it appears that some youth as young as 12 are beginning to put away some money for college. This is consistent with previous findings (Elliott et al. 2010). In a study of 51 fourth-grade youth in a college savings program, Elliott et 
al. (2010) found that youth who were in the school savings program were statistically more likely to perceive that saving is a way to help pay for college than youth in a comparison group.

Further, existing education research identifies parents' SES (i.e., family income and parents' education level) as one of the most important predictors of young adult's college progress. However, up until now, this research has largely ignored youth's school savings. A reason for this may be because few data sets include youth's savings variables along with data on youth's educational outcomes. The PSID and its supplements, while doing so imperfectly, provide one of the few opportunities to investigate this relationship. In this study, while controlling for youth's school savings, parents' education level has a significant association with college progress but income does not. Moreover, we find evidence that suggests that youth's school savings has independent effects on college progress from traditional SES variables. As a result, models that do not include youth's school savings may be underspecified.

While a goal of this study is to conduct an advance test of large-scale youth's savings policies, there are several important differences between the accounts examined in this study and CDA accounts like those that have been proposed in the ASPIRE Act and other popular education accounts such as Coverdell Education Savings Accounts, Uniform Gifts to Minors Ac, 529 college savings plans run by states, and Roth Individual Retirement Arrangements. These differences have implications for policy. Popular educational accounts offer their owners protection from taxation. In order not to be taxed, however, savings in these accounts typically cannot be withdrawn without penalty until youth reach college age, and the money must be spent on college-related expenses. As a result, these accounts can more aptly be defined as being nonliquid in nature. Unlike with these popular education accounts, youth can easily withdraw money from the accounts in this study and use that money without penalty.

Typically, these more popular education accounts have been developed to solve the short-term problem of financing college when youth reach college age; however, findings suggest that a better design might allow youth to access a portion of their savings on a more regular basis for day-to-day expenses. We speculate that the ability to use a portion of their savings for day-to-day expenses may help youth to associate savings with solving problems in their life that matter to them, further strengthening their sense of perceived control. Perceived control is one of the most robust predictors of student resilience and academic success (Skinner et al. 1990). Therefore, we suggest that youth's savings policies may want to allow youth to access a portion of their savings on a regular basis.

Conversely, there are positive aspects of CDAs, for example, that are not reflected in the traditional savings accounts examined in this study that may 
also have implications. Unlike the traditional savings accounts examined in this study, CDAs are built on an institutional theory of savings. From an institutional perspective, institutions promote and subsidize asset accumulation by reducing the cost of saving and the cognitive processing involved in saving; however, mainstream savings institutions do this inequitably, favoring middleand upper-income households and individuals. Because these types of program already exist for middle- and upper-income households, mechanisms, such as CDAs, are needed specifically for low-income and minority youth.

Practically speaking, in order for CDAs to serve as an alternative to loans, youth must be able to save fairly large sums of money. The institutional components of youth asset-building programs may provide youth with a way to promote saving by providing institutional assistance in the form of an initial deposit and a match (e.g., the youth puts a dollar in his or her account and the federal government puts an additional dollar in up to some specified amount per year), among other things. More specifically, institutional theorists have identified seven constructs that are believed to be important aspects of institutions designed to promote saving and asset accumulation: access, information, incentives, facilitation, expectations, restrictions, and security (Sherraden and Barr 2005). Access refers to eligibility and practicality; information includes both general financial information and information that is specific to a particular financial product or program; incentives include subsidies and rates of return; facilitation refers to any form of assistance in saving, especially making saving "automatic"; expectations are implicit or explicit suggestions about desirable saving, investment, or asset accumulation; and restrictions are rules that restrict access to or use of assets (Sherraden and Barr 2005). As a result, institutional theorists propose that youth are likely to accumulate more savings in CDAs than they would in a traditional savings account, for example. Increased savings means that they will have more money to pay for college, reducing the overall amount of debt they are likely to have to accumulate.

\section{Future Directions}

Future research should examine whether youth's savings effects vary by race and SES. Researchers may also want to examine whether having savings is associated with youth having higher expected amounts of savings in the future and whether expected savings serve as a mediator between youth's savings and college progress. In addition, research designs are needed that allow the researcher to test for causation. That is, does having youth's school savings cause youth to be on course? A type of CDA that is in the state's name with the youth as the beneficiary is being tested in a large experiment in Oklahoma called SEED for Oklahoma Kids (SEED OK). ${ }^{10}$ However, because the ac- 


\section{Staying on Course}

counts are issued at birth in 2004, it will be a number of years before researchers will be able to test this design as it relates to college progress. Until then, finding other data sets and ways of testing causal relationship is an important next step. Similarly, as a first step, temporal ordering is needed when testing mediation where youth's savings comes prior to expectations and expectations come prior to college progress.

\section{Conclusion}

Increasingly, college completion is seen as a necessary step toward achieving the American Dream. However, large disparities exist in graduation rates. For many families, current family income is not enough to finance college. Therefore, many have to rely on education loans that may be difficult to repay, leaving them strapped with debt much of their adulthood. Overall, findings suggest that policies such as CDAs that help parents and youth accumulate savings - especially savings for college - may increase college attendance and completion rates. 


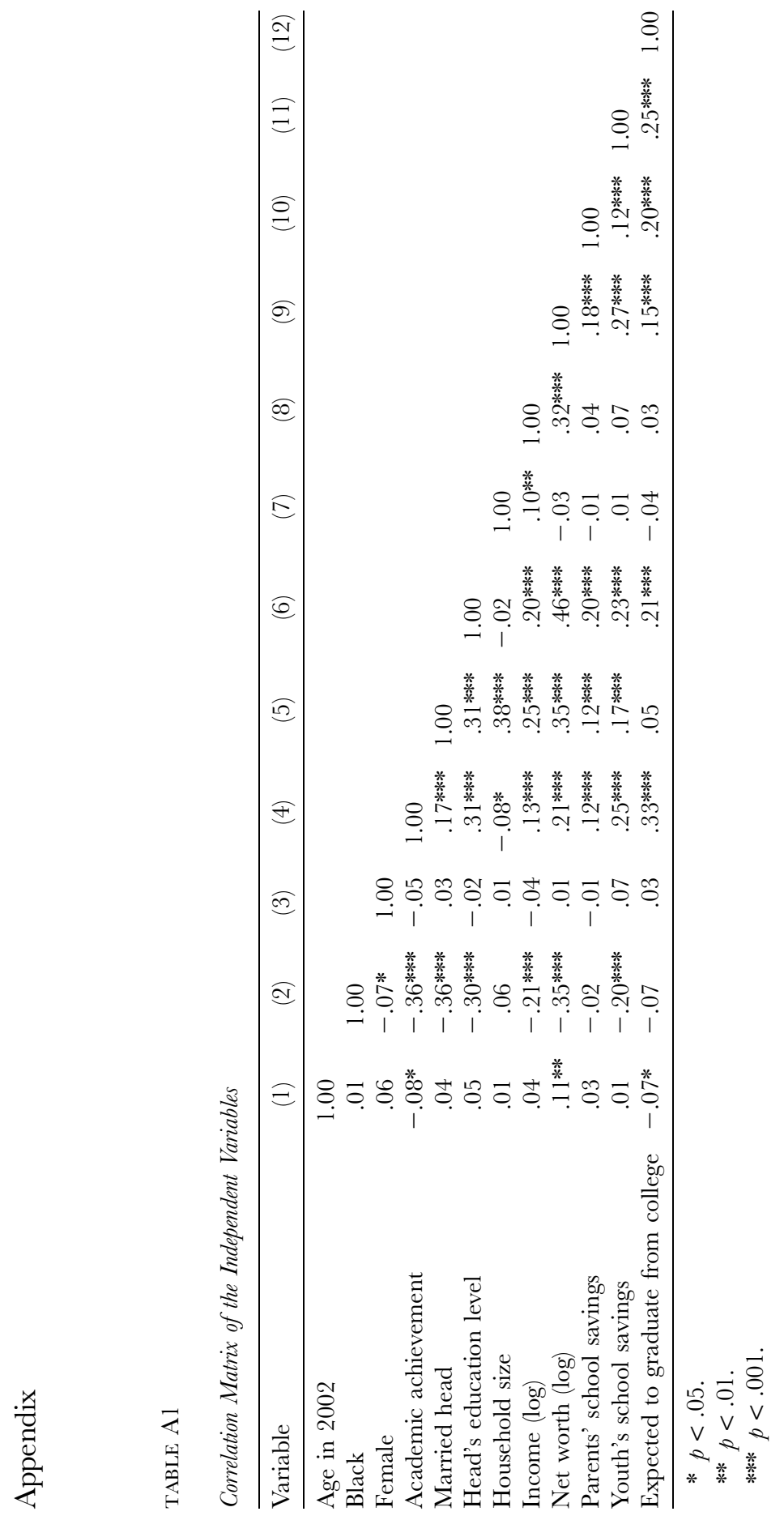




\section{Staying on Course}

\section{Notes}

This article is part of the College Savings Initiative, a research and policy design collaboration between the Center for Social Development at Washington University in St. Louis and the New America Foundation in Washington, DC. The College Savings Initiative is supported by the Lumina Foundation for Education and the Bill and Melinda Gates Foundation. The authors thank Michael Sherraden and Julia Stevens for comments.

1. College Board (2007b) uses data from full-time, first-year, dependent students at four-year colleges in 1995 who have completed a bachelor's degree by 2001. High income is defined as $\$ 70,000$; low income is defined as less than $\$ 40,000$.

2. At this writing, the ASPIRE Act remains on the Congressional agenda (http:// www.newamerica.net/publications/policy/aspire_act_bill_summary).

3. Choy and Carroll (2003) find that, during the 1999-2000 school year, the average unmet need for low-income students is between $\$ 4,000$ and $\$ 9,300$, depending on the type of college.

4. These figures only include federal loans. They do not include other types of borrowing for school such as credit cards or personal loans.

5. These categories are based on work done by Nam and Huang (2009).

6. The former category includes youth who have a graduate degree or are currently enrolled in a graduate program. The latter category includes those who have not graduated from high school, those with a high school diploma or GED who have not attended college, and those who have attended college but are not currently enrolled. Very few youth have graduated from college: 15 have two-year college degrees, 31 have four-year college degrees, two have graduate degrees, and four are currently in a graduate program.

7. Category amounts are based on those used in the U.S. Census Bureau's Current Population Report "Income in the United States, 2002" (De Navas-Walt et al. 2002). De-Navas-Walt et al. used five income categories; we recoded into three categories to increase the sample size within each group.

8. The frequencies of age are as follows: age $17=49$; age $18=193$; age $19=$ 171 ; age $20=204$; age $21=165$; age $22=171$; and age $23=45$. Even the 17 year-olds are no longer in high school.

9. Elliott (2009) is the only other study to use bootstrapping; however, he examined the relationship between youth's school savings and math achievement.

10. For more information on SEED OK, see http://csd.wustl.edu/AssetBuilding/ SEEDOK/.

\section{References}

Advisory Committee on Student Financial Assistance. 2002. Empty Promises: The Myth of College Access in America. Washington, DC: Department of Education.

Advisory Committee on Student Financial Assistance. 2006. Mortgaging Our Future: How Financial Barriers to College Undercut America's Global Competitiveness. Washington, DC: Advisory Committee on Student Financial Assistance.

American Bankers Association. 2009. "Teach Children to Save: Building a Generation of Savers," http://www.aba.com/ABAEF/tcts.htm.

$\rightarrow$ Baron, Reuben, and David Kenny. 1986. "The Moderator-Mediator Variable Dis- 
tinction in Social Psychological Research: Conceptual, Strategic, and Statistical Considerations." Journal of Personality and Social Psychology 51 (6): 1173-82.

Baum, Sandy. 1996. "New Directions in Student Loans: Intergenerational Implications." Journal of Student Financial Aid 26 (2): 7-18.

Baum, Sandy, and Jennifer Ma. 2009. Education Pays: The Benefits of Higher Education for Individuals and Society. New York: College Board.

$\rightarrow$ Blau, David M. 1999. "The Effect of Income on Child Development." Review of Economics and Statistics 81 (2): 261-76.

$\rightarrow$ Bollen, Kenneth, and Robert Stine. 1992. "Bootstrapping Goodness-of-Fit Measures in Structural Equation Models." Sociological Methods and Research 21 (2): 205-29.

Boshara, Ray. 2003. "Federal Policy and Asset Building." Social Development Issues 25 (1-2): $130-41$.

$\rightarrow$ Brooks-Gunn, Jeanne, and Greg Duncan. 1997. "The Effects of Poverty on Children." Children and Poverty 7 (2): 55-71.

Brown, William, Matthew Chingos, and Michael McPherson. 2009. Crossing the Finish Line: Completing College at America's Public Universities. Princeton, NJ: Princeton University Press.

Charles, Camille, Vincent Roscigno, and Kimberly Torres. 2007. "Racial Inequality and College Attendance: The Mediating Role of Parental Investments." Social Science Research 36 (1): 329-52.

Choy, Susan. 2002. Nontraditional Undergraduates: Findings from the Condition of Education, 2002. Washington, DC: National Center for Education Statistics.

Choy, Susan, and C. Dennis Carroll. 2003. How Families of Low- and Middle-Income Undergraduates Pay for College: Full-Time Dependent Students in 1999-2000. NCES 2003162. Washington, DC: U.S. Department of Education, National Center for Education Statistics.

Cline, Stephanie. 2005. "Denver Children Learn Financial Basics at Young Americans Center," http://www.allbusiness.com/north-america/united-states-colorado/925500-1.html.

Coleman, James. 1988. "Social Capital in the Creation of Human Capital." American Journal of Sociology 94 (suppl.): S95-S120.

Coleman, James, Ernest Campbell, Carol Hobson, James McPartland, Alexander Mood, and Frederic Weinfeld. 1966. Equality of Educational Opportunity. Washington: DC: Department of Health, Education, and Welfare.

College Board. 2007a. Education Pays: The Benefits of Higher Education for Individuals and Society. New York: College Board.

College Board. 2007b. "Trends in College Pricing," http://www.careercornerstone .org/pdf/universities/tuition07.pdf.

College Board. 2009. Trends in Student Aid: Trends in Higher Education Series. Washington, DC: College Board.

Conley, Dalton. 1999. Being Black, Living in the Red. Berkeley: University of California Press.

$\rightarrow$ Conley, Dalton. 2001. "Capital for College: Parental Assets and Postsecondary Schooling." Sociology of Education 74 (1): 59-72.

Council for Economic Education. 2010. "Program Highlights," http://www .councilforeconed.org/.

Cruce, Asheley. 2001. "A History of Progressive-Era School Savings Banking, 1870 to 1930." Working Paper no. 01-3. Center for Social Development, Washington University in St. Louis, http://varolifamily.com/PDFs/H/history-of-progressive.pdf.

Cruce, Asheley. 2002. "School-Based Savings Programs, 1930-2002." Working Paper no. 02-7. Center of Social Development, Washington University in St. Louis, http://www.varolifamily.com/PDFs/S/School-Based-Savings.pdf. 


\section{Staying on Course}

De Navas-Walt, Carmen, Robert Cleveland, and Bruce Webster. 2002. Income in the United States, 2002. P60-221. Washington, DC: U.S. Department of Commerce.

Destin, Mesmin. 2009. Assets, Inequality, and the Transition to Adulthood: An Analysis of the Panel Study of Income Dynamics. Issue brief. New York: Aspen Institute, Initiative on Financial Security.

$\rightarrow$ Elliott, William. 2009. "Children's College Aspirations and Expectations: The Potential Role of College Development Accounts (CDAs)." Children and Youth Services Review 31 (2): 274-83.

Elliott, William, and Sondra Beverly. Forthcoming. "The Role of Savings and Wealth in Reducing "Wilt" between Expectations and College Attendance." Fournal of Children and Poverty.

$\rightarrow$ Elliott, William, Margaret Sherraden, Lissa Johnson, and Baorong Guo. 2010. "Young Children's Perceptions of College and Saving: The Potential Role of Child Development Accounts." Children and Touth Services Review 32 (11): 1577-84.

Gouskova, Elena. 2001. "The 2002 PSID Child Development Supplement (CDS-II) Weights," http://psidonline.isr.umich.edu/CDS/questionnaires/cdsiiweights.pdf.

Grinstein-Weiss, Michal, Yeong Hun Yeo, Kate Irish, and Min Zhan. 2009. "Parental Assets: A Pathway to Positive Child Educational Outcomes." Fournal of Sociology and Social Welfare 36 (1): 61-85.

Haveman, Robert, and Kathryn Wilson. 2007. "Access, Matriculation, and Graduation." In Economic Inequality and Higher Education Access, Persistence, and Success, ed. Stacey Dickert-Conlin and Ross Rubenstein, 17-43. New York: Russell Sage Foundation.

Haveman, Robert, and Edward Wolff. 2005. "Who Are the Asset Poor? Levels, Trends, and Composition, 1983-1998." In Inclusion in the American Dream: Assets, Poverty, and Public Policy, ed. Michael Sherraden, 61-86. New York: Oxford University Press.

$\rightarrow$ Heller, Donald. 1997. "Student Price Response in Higher Education: An Update to Leslie and Brinkman." Journal of Higher Education 68 (6): 624-59.

$\rightarrow$ Heller, Donald, and Kimberly Rogers. 2006. "Shifting the Burden: Public and Private Financing of Higher Education in the United States and Implications for Europe." Tertiary Education and Management 12 (2): 91-117.

$\rightarrow$ Henretta, John, and Richard Campbell. 1978. "Net Worth as an Aspect of Status." American Fournal of Sociology 83 (5): 1204-23.

Hill, Catherine, Gordon, Winston, and Stephanie Boyd. 2004. "Affordability: Family Incomes and Net Prices at Highly Selective Private College and Universities." Discussion Paper no. 66r, Williams Project on Higher Education, http://www .econstor.eu/bitstream/10419/23513/1/DP-66r.pdf.

Hochschild, Jennifer, and Nathan Scovronick. 2003. The American Dream and the Public Schools. New York: Oxford University Press.

$\rightarrow$ Huang, Jin, Baorong Guo, Youngmi Kim, and Michael Sherraden. 2010. "Parental Income, Assets, Borrowing Constraints, and Children's Post-Secondary Education." Children and Touth Services Review 32 (4): 585-94.

Jez, Su Jin 2008. The Influence of Wealth and Race in Four-Year College Attendance. Berkeley: Center for Studies in Higher Education, University of California, Berkeley.

Junior Achievement. 2009. "Educating Students Worldwide," http://www.ja.org/.

Leslie, Larry, and Paul Brinkman. 1988. The Economic Value of Higher Education. New York: American Council on Education, Macmillan.

Little, Roderick, and Donald Rubin. 1987. Statistical Analysis with Missing Data. New York: Wiley.

$\rightarrow$ MacKinnon, David, Chondra Lockwood, and Jason Williams. 2004. "Confidence Limits for the Indirect Effect: Distribution of the Product and Resampling Methods." Multivariate Behavioral Research 39 (1): 99-128. 


\section{Elliott and Beverly}

Mainieri, Tina. 2006. "The Panel Study of Income Dynamics Child Development Supplement: User Guide for CDS-II," http://psidonline.isr.umich.edu/CDS/ cdsii_userGd.pdf.

$\rightarrow$ Mathieu, John, and Scott R. Taylor. 2006. "Clarifying Conditions and Decision Points for Mediational Type Inferences in Organizational Behavior.” Journal of Organizational Behavior 27 (8): 1031-56.

Mau, Wei-Cheng. 1995. "Educational Planning and Academic Achievement of Middle School Students: A Racial and Cultural Comparison." Journal of Counseling and Development 73 (5): 518-26.

Mayer, Susan. 1997. What Money Can't Buy: Family Income and Children's Life Chances. Cambridge, MA: Harvard University Press.

McPherson, Michael, and Morton Schapiro. 1998. The Student Aid Game: Meeting Need and Rewarding Talent in American Higher Education. Princeton, NJ: Princeton University Press.

Mooney, Christopher, and Robert Duval. 1993. Bootstrapping: A Nonparametric Approach to Statistical Inference. Newbury Park, CA: Sage.

$\rightarrow$ Nam, Yunju, and Jin Huang. 2009. "Equal Opportunity for All? Parental Economic Resources and Children's Educational Achievement." Children and Youth Services Review 31 (6): 625-34.

$\rightarrow$ O'Connor, Noga, Floyd Hammack, and Marc Scott. 2010. "Social Capital, Financial Knowledge, and Hispanic Student College Choices." Research in Higher Education 51 (3): 195-219.

Oliver, Melvin, and Thomas Shapiro. 2006. Black Wealth/White Wealth: A New Perspective on Racial Inequality (10th anniversary ed.). New York: Routledge.

$\rightarrow$ Orr, A. 2003. "Black-White Differences in Achievement: The Importance of Wealth." Sociology of Education 76 (4): 281-304.

Paulsen, Michael. 2001. "The Economics of Human Capital and Investment in Higher Education." In The Finance of Higher Education: Theory, Research, Policy and Practice, ed. Michael Paulsen and John Smart, 55-94. New York: Agathon.

$\rightarrow$ Porfeli, Erik, Chuang Wang, Robert Audette, Ann McColl, and Bob Algozzine. 2009. "Influence of Social and Community Capital on Student Achievement in a Large Urban School District." Education and Urban Society 42 (1): 72-95.

$\rightarrow$ Preacher, Kristopher, and Andrew Hayes. 2004. "SPSS and SAS Procedures for Estimating Indirect Effects in Simple Mediation Models." Behavior Research Methods 36 (4): 717-31.

SAS Institute. 2008. "SAS/STAT® 9.2 User's Guide," http://support.sas.com/ documentation/cdl/en/statugsurveylogistic/61836/PDF/default/statugsurveylogistic .pdf.

Schreiner, Mark, and Michael Sherraden, Can the Poor Save? Saving and Asset Building in Individual Development Accounts. New Brusnwick, NJ: Transaction Publishers.

Sherraden, Michael. 1991. Assets and the Poor: A New American Welfare Policy. Armonk, NY: M. E. Sharpe.

Sherraden, Michael. 2005. Inclusion in the American Dream: Assets, Poverty, and Public Policy. New York: Oxford University Press.

Sherraden, Michael, and Michael Barr. 2005. "Institutions and Inclusion in Saving Policy." In Building Assets, Building Wealth; Creating Wealth in Low-Income Communities, ed. Nicholas Retsinas and Eric Belsky. Washington DC: Brookings Institution Press.

Shrout, Patrick, and Niall Bolger. 2002. "Mediation in Experimental and Nonexperimental Studies: New Procedures and Recommendations." Psychological Methods 7 (4): $422-45$. 


\section{Staying on Course}

$\rightarrow$ Sirin, Selcuk. 2005. "Socioeconomic Status and Academic Achievement: A Metaanalytic Review of Research." Review of Educational Research 75 (3): 417-53.

$\rightarrow$ Skinner, Ellen, James Wellborn, and James Connell. 1990. "What It Takes to Do Well in School and Whether I've Got It: A Process Model of Perceived Control and Children's Engagement and Achievement in School." Journal of Educational Psychology 82 (1): 22-32.

$\rightarrow$ Sobel, Michael. 1982. "Asymptotic Confidence Intervals for Indirect Effects in Structural Equation Models.” Sociological Methodology 13:290-312.

Sonuga-Barke, Edmund J. S., and Paul Webley. 1993. Children's Saving: A Study in Development of Economic Behavior. Hillsdale, NJ: Erlbaum.

Steele, Patricia, and Sandy Baum. 2009. How Much Are College Students Borrowing.? College Board, http://professionals.collegeboard.com/profdownload/cb-policy-brief-collegestu-borrowing-aug-2009.pdf.

$\rightarrow$ Stratton, Leslie, Dennis O’Toole, and James Wetzel. 2007. “Are the Factors Affecting Dropout Behavior Related to Initial Enrollment Intensity for College Undergraduates?" Research in Higher Education 48:453-85.

Sunstein, Cass. 1997. Free Markets and Social Justice. New York: Oxford University Press.

$\rightarrow$ Williams Shanks, Trina, and Mesmin Destin. 2009. "Parental Expectations and Educational Outcomes for Young African American Adults: Do Household Assets Matter?" Race and Social Problems 1 (1): 27-35.

$\rightarrow$ Yeung, W. Jean, Miriam Linver, and Jeanne Brooks-Gunn. 2002. "How Money Matters for Young Children's Development: Parental Investment and Family Process." Child Development 73 (6): 1861-79.

Young American Bankers. 2011. http://www.yacenter.org/young-americans-bank.

Young Americans Center for Financial Education. 2010. "About Us: Why Young Americans?" http://www.yacenter.org/.

$\rightarrow$ Zhan, Min. 2006. "Assets, Parental Expectations and Involvement, and Children's Educational Performance." Children and Youth Services Review 28 (8): 961-75.

$\rightarrow$ Zhan, Min, and Michael Sherraden. 2003. "Assets, Expectations, and Children's Educational Achievement in Female-Headed Households." Social Service Review 77 (2): 191-211.

Zhan, Min, and Michael Sherraden. 2009. "Assets and Liabilities, Educational Expectations, and Children's College Degree Attainment," CSD Working Paper no. 09-60, Center for Social Development, Washington University, St. Louis, MO.

Zhan, Min, and Michael Sherraden. 2010. "Assets and Liabilities, Race/Ethnicity, and Children's College Education.” CSD Working Paper no. 10-08, Center for Social Development, Washington University, St. Louis, MO. 